\title{
COURT INTERPRETING 2009: AN UNDERVALUED AND MISUNDERSTOOD PROFESSION? OR: WILL JUSTICE SPEAK?
}

\author{
Ruth Morris \\ Department of Interpreting and Translation Studies, Bar-Ilan University
}

\begin{abstract}
The article addresses a number of topical issues relating to court interpreting. After examining a number of issues discussed among US interpreters in July 2009, it considers the provision of court interpreting in a number of different English-speaking jurisdictions, including the position of agencies. It presents the cost of a lack of judicial awareness of the issues involved in providing competent interpreting in legal proceedings, and looks at how rare languages are dealt with in the United States. It examines best practice and how this can quickly turn into worst practice. It considers the situation in Canada's Province of Ontario, where a class action has been brought against the Ministry of the Attorney General for failing to provide competent interpreting services. The discussion poses a number of questions, and considers whether court interpreting is condemned to be an undervalued and misunderstood profession in many jurisdictions, or whether there is reason to hope for improvement.
\end{abstract}

\section{Résumé}

Cet article aborde des questions d'actualité liées à l'interprétation au tribunal. Après avoir étudié plusieurs sujets débattus par des interprètes aux Etats-Unis en juillet 2009, l'article se penche sur la fourniture de l'interprétation auprès des tribunaux dans divers systèmes juridiques anglophones, ainsi que sur l'attitude des agences. Il est fait état du manque de sensibilité du milieu judiciaire et de la gestion des langues rares aux Etats-Unis. Une étude des meilleures pratiques et de leur évolution potentielle et rapide en mauvaises pratiques, est réalisée. Larticle dresse un état des lieux de l'interprétation auprès des tribunaux dans la Province de l'Ontario au Canada où un recours collectif a été entamé contre le Ministère du Procureur général face à son incapacité à fournir des services d'interprétation compétents. La discussion porte sur 
plusieurs questions et s'interroge sur l'avenir de l'interprétation au tribunal: est-elle condamnée à être sous-estimée et incomprise dans de nombreuses juridictions ou y a-t-il lieu d'espérer une amélioration?

\section{Keywords}

Reasonable understanding. Competent. Professional. Outsourcing. Arrangements.

\section{Mots-clé}

Compréhension raisonnable. Compétent. Professionnel. Externalisation. Dispositions. 


\section{Introduction: Interpreters in the US legal system - July 2009}

In July 2009, Wisconsin Democrat Senator Herb Kohl introduced the State Court Interpreter Grant Program Act (S. 1329), designed to create a federal grant program in order to ensure that high quality interpreter services are made available to non-English speakers appearing in state courts in the USA. NAJIT, that country's National Association of Judiciary Interpreters and Translators, issued a letter of support for Senator Kohl's Act (NAJIT 2009).

At the same time, a job advertisement for a part-time Spanish interpreter at the Franklin County Municipal Court, Ohio, was circulated on the NAJIT listserve. The overview indicated that "[t]he Court employs Spanish-language interpreters to provide interpreting and translating services to Spanish-speaking persons... Interpreters assist the judges, magistrates, attorneys, Court employees, and others in communicating with Spanish-speaking defendants, victims, witnesses, family members, and others having business before the Court". However, the eleven specifications for this position were extremely comprehensive, and combined not only job specifications but also elements of a code of ethics and practice:

1. Perform three types of court interpreting: sight interpreting, consecutive interpreting, and simultaneous interpreting.

2. Provide spoken language Spanish interpretation services to the Court.

3. Sight interpret Spanish or English documents as required during Court proceedings, interviews, and other Court-related communicative events.

4. Assist the Court with communication with Spanish speaking defendants, victims, witnesses, and other individuals as necessary.

5. Produce written translations of documents, such as official Court forms, public signs, notices, posters, and Court correspondence.

6. Maintain the confidentiality of conversations that are of a confidential nature and serve impartially as required by court interpreter ethics.

7. Perform interpreter duties according to established standards and in an accurate, impartial manner, and abide by any applicable rules or standards for interpreters adopted by the Supreme Court of Ohio. 
8. Interpret in a manner that includes everything that is said, preserves the tone and level of language, and neither changes nor adds anything to what is said.

9. Attend ongoing training to improve and maintain Spanish interpreter skills, as well as ongoing training regarding court interpreter standards of ethics and conduct, including any applicable rules or standards for interpreters adopted by the Supreme Court of Ohio.

10. Perform other duties as assigned.

11. May be assigned to other positions in other departments of the Court if needed.

The advertisement stated that candidates "must have a combination of education, experience, skills, and personal characteristics that demonstrate the candidate's ability to perform the duties of the position". The successful candidate was expected to have at least the following qualifications and meet the following requirements:

1. A high school diploma or equivalent.

2. Ability to read, write, speak, understand, and communicate fluently in both Spanish and English.

3. Two years of full-time experience in Spanish interpreting and translating in a public setting.

4. Basic understanding of legal terminology and procedures.

5. Ability to render precise, accurate interpretations from English into Spanish and Spanish into English without omissions or additions.

6. Ability to render interpretations promptly without hesitation.

7. Thorough knowledge of the methods, techniques and procedures used in interpreting in consecutive and simultaneous modes.

8. Ability to interpret both simultaneously and consecutively.

9. Ability to sight interpret Spanish and English documents.

10. Knowledge of the ethical codes of interpreters and protocol of interpreting, including any applicable rules or standards for interpreters adopted by the Supreme Court of Ohio.

11. Knowledge of common office practices, procedures, and equipment.

12. Proficiency in operating a personal computer and using, or being able to learn, Microsoft Office products including Word, Outlook, and Excel.

13. Have good time management skills; be highly organized and detail-oriented. 
14. Ability to prioritize work, work independently without daily supervision, perform a variety of duties, and manage a variety of projects simultaneously in a high pressure atmosphere under sometimes severe time constraints.

15. Ability to effectively and professionally communicate verbally and in writing in English to diverse audiences.

16. Pleasant personality; ability to interact and maintain effective working relationships with judges, other elected officials, employees, law enforcement officers, lawyers, and other conducting business with the Court.

17. Conscious of and sensitive to the diversity within the Court's jurisdiction and able to interact professionally with this diverse population of people from many different geographic, socioeconomic, religious, racial, and ethnic backgrounds on a regular basis.

18. Professional appearance and demeanor appropriate for the position and expected of a representative of elected officials.

19. Demonstrated dependability, reliability, and excellent attendance record.

20. Patience, objectivity, maturity, effectiveness under stress, initiative, adaptability, leadership, and sound judgment.

In addition to this highly complete listing of desirable qualities in a court interpreter - qualities which the advertisement thinks can be met by somebody with a high school diploma, and which seem to require the individual to be a translator as well as office coordinator and administrator - the advertisement goes on to specify that preferred qualifications include "an associate's or bachelor's degree in Spanish or Court Interpreting; a certificate or other evidence of having completed a course on court interpreter ethics and conduct standards offered by the Ohio Supreme Court, the Franklin County Municipal Court, or an equivalent training; certification by a member of the Consortium for State Court Interpreters Certification or Court Interpreter Certification from the Administrative Office of the U.S. Courts; and previous interpreting experience in a judicial, law enforcement, or legal environment". And just in case applicants have extra skills to offer, for good measure the point is made that additional consideration would be given to applicants who have any of the following qualifications: "paralegal certification or other advanced schooling in any subject; fluency in a language other than Spanish or English; the ability to speak and write a language commonly used by people 
of Somalia for whom English is a second language; or proficiency in American Sign Language (ASL)".

The author of the advertisement has done a commendable job in describing the complete range of attributes that should be possessed by the perfect interpreter/translator employee working in the legal system. However, this part-time position pays $\$ 18.54$ an hour, equivalent to $\$ 19,281.60$ a year. In response, one comment on the NAJIT listserve was: "This is ludicrous... long on requirements and too short on pay!" Another contribution to the thread read: "It gets worse. I spoke to an owner of an interpreting agency in Columbus, $\mathrm{OH}$ last week about a possible assignment. She informed me that they pay $\$ 20$ an hour for free lance court interpreters and $\$ 12$ an hour for medical interpreters!" (emphasis in original). A third communication suggested, "Perhaps a NAJIT committee could help these states/hiring organizations come up with realistic fees befitting the preparation and credentials needed for our profession, not to mention cost of living, business costs, etc.? This issue is not Ohio's alone, our profession is undervalued and misunderstood in many places across the nation". And last, in hope but perhaps unrealistically: "If there was a law created by Congress for this profession, then there may be standards placed on wages that are uniform across the US".

With regard to the NAJIT letter of support for Senator Kohl's initiative, one member observed in a cri de coeur which correctly identifies the basic predicament of those who wish to provide professional interpreting services to the legal system:

It is infuriating ... that although states purport to want to professionalize interpreting on the one hand, on the other, they are awarding contracts for interpreting to agencies that want to pay less and less every year (since that is how they were able to win the contracts in the first place), thus creating a situation where professionals are supposed to work for the pay that laborers make, while having to spend money on education, testing, certification, professional courses, dictionaries, and all of the other things that make us professionals.

Added to the panoply of July 2009 documents that give court interpreters pause for thought is the Brennan Center for Justice report on Language Access in State Courts (Abel 2009). Its executive summary identifies the following hair-raising facts:

Across the country, people are stuck in a Kafkaesque nightmare: they must go to court to protect their children, homes or safety, but they can neither communicate nor understand what is happening. Nearly 25 million people in this country have limited proficiency in English (LEP), meaning that they cannot protect their rights in court without the assistance of an interpreter. At least 
13 million of those people live in states that do not require their courts to provide interpreters to LEP individuals in most types of civil cases. Another 6 million live in states that undercut their commitment to provide interpreters by charging for them. And many live in states that do not ensure that the "interpreters" they provide can speak English, speak the language to be interpreted, or know how to interpret in the specialized courtroom setting. Many of those states are violating Title VI of the Civil Rights Act, which requires state courts receiving federal assistance to provide interpreters to people who need them. (Abel 2009:1)

Abel goes on to identify the high costs of state courts' failure to provide competent interpreters to LEP people in civil cases. Not only do individuals suffer because they cannot protect their children, their homes, or their safety. "Courts suffer because they cannot make accurate findings, and because communities lose faith in the justice system" (Abel 2009:1). Furthermore, society suffers because its civil laws - guaranteeing the minimum wage, and barring domestic violence and illegal eviction - cannot be enforced. Clearly, competent interpreters to work in the legal system are a necessity in the United States, but at the time of writing they are not available in sufficient numbers, whether because of a shortage of qualified individuals, failure on the part of the authorities to employ them, or insufficiently attractive conditions.

In the United States, the federal Civil Rights Act requires state courts that receive federal funds to provide interpreters to LEP individuals in all civil and criminal cases, on the same footing as access to the courts, due process, equal protection and the right to counsel. Abel makes the point that the interpreters must be provided without charge. Courts must ensure that interpreters have essential language and interpreting skills. Judges and other court personnel must know when and how to use interpreters. And, courts must accord LEP individuals the same treatment they accord other individuals (Abel 2009:1).

The points cited above from the Brennan Report's executive summary are a mixture of legal requirements and common sense. However, throughout the USA, courts are shirking their responsibilities. For the report, interpretation services were examined in 35 states. The findings were as follows: (1) 46\% fail to require that interpreters be provided in all civil cases; (2) 80\% fail to guarantee that the courts will pay for the interpreters they provide, with the result that many people who need interpreters do not in fact receive them; and (3) $37 \%$ fail to require the use of credentialed interpreters, even when such interpreters are available (Abel 2009: 2). 
Given this picture of a very specific United States legislative background and the gaping loopholes that exist in practice, this paper will now look at related situations in various English-speaking countries.

\section{Judicial professionals' perceptions of interpreters}

In some parts of the English-speaking legal world, acts and regulations have been passed with the goal of guaranteeing the provision of language-mediation services in the legal system - largely, but not always exclusively, the criminal justice system. In the United States, following the passing of the Court Interpreter's Act of 1978 (28 USC 1827), "each federal court is required to provide, at judiciary expense, a certified or otherwise qualified interpreter in judicial proceedings instituted by the United States for a party who speaks only or primarily a language other than English" (U.S. Code Title 28, Part V, Chapter 119, § 1827. Interpreters in courts of the United States, http:// www4.law.cornell.edu/uscode/28/1827.html). Among other things, the Act stipulates: "The Director of the Administrative Office of the United States Courts shall establish a program to facilitate the use of certified and otherwise qualified interpreters in judicial proceedings instituted by the United States". Following the passing of the Act, changes have also taken place on state level too that have led to various acts, regulations and programs relating to the provision and qualifications of interpreters in legal systems.

However, basically every system has its Achilles' heel. There is frequently some factor - often due to a particular person, or an all-pervading ethos - that makes systems tend to either the wonderful or the terrible. Sometimes plain economic factors may dominate. At other times, local politics may play the same role. Thus a particular state's flourishing interpreter program may deteriorate out of all recognition with the departure of a particular individual from a state court administrator's office or similar. Alternatively, a new supreme court justice may have priorities that do not include interpreter issues, and hence a program may be only able to coast along, perhaps offering nothing more than testing and certification. Although some individuals may be dedicated to access-to-justice issues, a great deal will depend on actually obtaining funding grants, which in cash-strapped times are likely to become increasingly hard to obtain. To a large extent, such factors lead to many systems having to start all over and duplicate much of what was originally accomplished when a program was initially established. For an account of a demise of this type, see "Requiem for an Interpreters Office, 1985 - 2001" (Anonymous: Proteus, NAJIT Newsletter, 10:3). 
As a result, even if the longed-for situation comes about where judicial professionals come to perceive interpreters as professionals providing an invaluable system in their legal systems, financial and administrative aspects may lead to a deterioration in the quality of the interpreters recruited for their courts. It is a rare judge who sees fit to personally and relentlessly pursue issues relating to court interpreters in his courthouse, as did Judge Casey Hill in the Brampton courthouse in Toronto (see Canada: Mr. Justice Casey Hill and Sidhu below). The fact that regulations frequently provide "let-out clauses" allowing waivers from credentialing in the case of rare languages is often used by administrations as an excuse not to insist on adherence to quality standards that are set down in regulations and tenders. The result is a lamentable deterioration in quality or a failure to uphold what were intended to be professional standards.

\section{Court interpreting in California, England and Wales, Ireland and Scotland}

Judicial interpreters' working conditions, career prospects, pay and conditions vary greatly worldwide. There is also considerable diversity in arrangements for the provision of interpreters to the legal system. In addition, a given situation may change out of all recognition as a result of a policy switch, with interpreters who have made substantial efforts to become trained, qualified and experienced suddenly finding that the basic premises on which they based their professional decisions have altered out of all proportion. A professional profile that was expected to put the interpreter in a relatively high socio-economic bracket may be transformed almost overnight as a result of administrative decisions from on high, as well as commercial decisions at the bottom of the pyramid.

Career aspects are frequently a thorny issue, even in California, which is a relatively linguistically enlightened jurisdiction. Interpreter pay levels may remain unchanged for many years, with advancement for interpreters an alien concept to administrations. In 2007 Los Angeles County court interpreters went on strike for six weeks but failed to gain a desired pay increase. Interpreters were seeking salary steps, to provide pay increases based on years of service, arguing that Court employees were entitled to this. As one interpreter put it, "'everyone would agree that's a good starting salary,' but without annual pay increases, 'our starting salary is our ending salary. There is no career path"' (Hong 2007). In all settings, court personnel may treat court interpreters as complete outsiders, even if they regularly work in the court system and are legally recognized as "officers of the court" (R. v. Sidhu, para. 292). Vital 
advance access to documentation is often refused to interpreters; sometimes, however, court staff are amenable to requests, being aware of interpreters' need to prepare. Interpreter frustration can relate to many issues, and not just monetary ones.

The new millennium has brought a marked trend towards outsourcing the provision of judicial interpreters to commercial agencies. Overall, experiences have not been positive. As the following survey of a number of Englishspeaking jurisdictions will show, whatever actual arrangement is chosen in order to deal with the provision of interpreting services in the legal system whether it is to use commercial agencies, a national register, an office of court interpreters, or non-profit state or private corporations - it is only as good as those who run, oversee, administer and supervise these entities. What is good must be kept that way and further improved; what does not work properly must be scrapped and a viable alternative introduced. Training, testing, certification, quality assurance, efficiency and "delivery of the goods" in the form of competent language mediation for the legal system in a given country are (or should be) universal requirements. For a variety of reasons, few countries manage to consistently achieve good practice in all of these.

Identifying a problem, researching the area or areas in which it exists, making recommendations for policy and practical steps to address the problem is a common approach. It is one that was adopted in the early 1990s in Britain with regard to interpreting in the legal system. At first, all seemed well. A system of interpreters competent to work with the public services called the NRPSI - National Register of Public Service Interpreters - was introduced in 1994. Such individuals were required to be qualified in at least one of four options: English law, Scottish law, health and local government-related services. The body currently in charge of the Register - a company called The NRPSI Ltd (a wholly owned, not-for-profit subsidiary of the Chartered Institute of Linguists) - states that its role is "to maintain a register of Public Service Interpreters" (PSIs). People on the Register were supposed to be holders of the industry benchmark Diploma in Public Service Interpreting (DPSI). Interpreters whose names appear on the Register are told that the latter is dispatched to subscribers - public service organisations and agencies that they work through - who, it assures interpreters, "will contact you direct for work". It is at pains to point out that "[t] he National Register cannot guarantee a steady source of income". Furthermore, it states, "The National Register does not commission interpreters as an agency would. Therefore public service organisations that subscribe to the National Register save on unnecessary agency charges and interpreters are able to negotiate their pay directly with the public 
service" (http://www.nrpsi.co.uk/news/index.htm). In reality, however, outsourcing to commercial agencies has become dominant in various parts of Great Britain. In this connection, the NRPSI chair, Brooke Townsley, made a number of points in the May 2007 National Register Newsletter. He admitted that there was much to be done at the NRPSI and noted that the NRPSI "can and must deal with the issues that it is empowered to address". Among these are "concerns about the nature and function of the register, about the availability of the register and to whom, and the responsiveness of the register to its registrants". Other critical issues need to be addressed by the public service interpreting profession through its professional membership bodies and trades unions, in conjunction with service providers. "Among these are issues of terms and conditions for all PSIs, standardisation of remuneration, outsourcing contracts and the activity of agencies and intermediaries". He finishes on this note: "I hope some of the concerns that rightfully belong to the NRPSI are addressed in this newsletter. I don't expect it to resolve them. It is, however, a start" (Townsley 2007).

Some of the issues hinted at by Townsley have subsequently become highly controversial on the British public service interpreting scene, and should be borne in mind by anyone considering following the British example. Thus available qualified, competent interpreters who are members of the Register, which has somehow been "acquired" by certain commercial agencies, are reportedly being forced to either work through the latter, at a fee far below that which they had expected to be paid in return for their investment in their qualifications and careers, or to largely remain unemployed. The interpreters whom the agencies actually provide are often unqualified, even though frequently qualified interpreters are available. A number of known legal cases in England and Wales which failed as a result of the incompetent interpretation resulting from this situation, whether at the police station or in courts, have been documented (Interpreters and Translators Bulletin. [n.d.] "Malpractices Dossier").

A similar cautionary tale comes from Ireland, where the American Lionbridge company was awarded a four-year court interpreters contract in 2006, and finally began supplying individuals in March 2007, judges were soon complaining about the quality of individuals sent to interpret in their courts, as well as the company's inefficient assignment practices. Reportedly, when the Courts Service put out a request for tender for interpreting services in 2005 they set the bar too low, arguing at the time that there were not enough qualified interpreters in the country and consequently they had to make do with what was available. Writing in the October 2007 bulletin of the local 
translators' and interpreters' association, the ITIA, its secretary, Mary Phelan, observed that all interpreters working in the courts were allegedly interviewed by Lionbridge and "must attend a one-day training course. Most are speakers of other languages rather than trained interpreters. A one-day training course is obviously totally insufficient to train court interpreters" (Phelan 2007). Worryingly, although the Courts Service spent over two million euros on interpreting in 2006, there is no provision for monitoring the standard of interpreting or for testing interpreters to ensure that they meet basic minimum standards.

According to Phelan, the Courts Service paid Lionbridge €46 per hour. In turn, Lionbridge paid either $€ 25$ or $€ 20$ or $€ 17.50$ to the interpreters. Reports of $€ 15$ per hour have even been heard. The rates varied depending on when the interpreters were recruited - those recruited more recently were paid less. Phelan comments that the reduction in pay was an alarming development. Interpreters used to complain that the hourly rate never increased despite inflation, but they never expected such reductions. Phelan suggested that Lionbridge favoured the more recently recruited interpreters for interpreting assignments because they cost less. The ITIA has well qualified, experienced interpreters in a number of languages, she points out, but they are not prioritised for work in the courts. Many members refuse to take on this type of work because the rate of pay is far too low for experienced, competent interpreters who can work in other sectors (conference/business) for much higher rates where they are paid per day or per half day. Indeed, many comment that Lionbridge pays reasonable rates for translation work.

Two newspaper articles in the same issue of the ITIA Bulletin also provide corroboration of reports from court interpreters who observed that Lionbridge's provision of interpreters was not working. Thus in the Cork District Court there were two interpreters for Polish when only one was required, whereas in Letterkenny District Court no Polish interpreter was available. Phelan observes that clearly something was wrong with the booking system if this was happening across the country. She made the point that not only should there be no problem locating Polish interpreters; there were many highly qualified Polish interpreters in Ireland, many of them holding postgraduate degrees in Translation and Interpreting (Phelan 2007: 5). Phelan concludes her article with a number of pointed and far from rhetorical questions:

Our members tell us of court cases where it is quite obvious to onlookers that the interpreters are interpreting only a fraction of what is said. What is 
the point of spending over two million euros on interpreting if the service provided is largely inadequate? (Phelan 2007: 4)

Her conclusion: "The Courts Service and Lionbridge have totally underestimated the level of difficulty of court interpreting".

How long are we going to have to wait for the Courts Service to improve the situation? There is an urgent need for proper, accredited training for court interpreters along with independent testing. Court interpreting should be seen as a viable profession for the languages most in demand. Do we really have to wait for a miscarriage of justice for the situation to change? (Phelan 2007: 3-4)

In the same edition of the ITIA Bulletin, the editor, Elizabeth Hayes, comments that these are "difficult times for qualified, competent interpreters in Ireland". She goes on to observe that when Lionbridge won the contract for the courts, the main concerns to the ITIA were rates and quality. Rates have indeed been slashed but even more worrying, on a medium- to long-term basis, is the question of quality. For people who perhaps do not come into contact regularly with the translation and interpreting world, she says, perceptions of who an interpreter is and what they do will be seriously damaged by media reports of what is happening in the courts. "Incompetent, unqualified bilingual people (I hesitate to call them interpreters) are being employed to do work that should be reserved for professionals. The reputation of all our interpreters is at stake here" (Hayes 2007: 1).

As a case study of pernicious practice inadvertently generated by attempts to improve efficiency and quality, the researcher can do no better than to examine the Scottish situation. During the writing of the present article, several reports appeared concerning the provision of court interpreting in Scotland's criminal justice system (Lalmy 2009, McLaughlin 2009, Taylor 2009), in addition to earlier publications that addressed the same issue. These include a study about immigration lawyers' difficulties with interpreters in Glasgow (Theiner 2003), a May 2009 report in Journal Online - The Members' Magazine of the Law Society of Scotland entitled "Court interpreting service put out to tender. $\mathrm{f} 6 \mathrm{~m}$ contract offered to improve quality", an article headed "Justice system compromised by unqualified interpreters: Fears of miscarriages in cases involving migrants" (Bynorth 2008), and The Scotsman's somewhat sensationalist "Translation errors may see criminals escape" (Howie 2007).

In particular, a study of Foreign Language Interpreters in the Scottish Criminal Courts (1998) was commissioned "in response to concern about the arrangements for and standards of the provision of foreign language interpreters in the Scottish courts". The concern arose from the results of research 
conducted in England and Wales in 1991 which concluded that arrangements were poorly developed and that interpreters were often inadequately trained and qualified. The 1998 Scottish research, which covered the whole of the country, aimed to provide a geographical portrait of the use of foreign language interpreters in the criminal courts, to establish the quality of service being provided, and to identify, where possible, areas in which the service could be improved. Based on the study's research, it can be seen that over the last decade, even following the influx of migrants to Scotland in the early part of the millennium nothing has changed - except perhaps for the worse. The summary refers to the fact that "there are instances where the quality of court interpreting has been poor. This is most evident from interpreters themselves who felt they did not provide an adequate service on their first assignments". As has been shown, ten years later members of the legal profession and professional interpreters are themselves acting as whistleblowers on the system's inadequacies. The report's summary goes on to state that the difficulties identified show the need for greater training of interpreters to prepare them for court work. "This, at its most basic level, should cover the do's and don'ts of court interpreting and the need for training in legal terminology also requires to be addressed". Written prior to the arrival of large numbers of migrants from Eastern Europe, the report stated: "One potential problem is that an increased effort in terms of training could mean valuable resources are used to train 'one off' interpreters as currently the low volume of business means that many interpreters only work in court once or a very few times. Cases do not arise often enough to keep court interpreters in regular employment". While this is a standard problem in all systems, with larger numbers of non-English speakers, today the argument is less persuasive. The last point in the report's summary has remained just as valid as ever: "The low rate of pay was also cited as a problem related to the competence of interpreters".

The content of all these documents indicates that the use of many unqualified, untrained, inexperienced and unsuitable so-called interpreters for legal work has led over the years to below-standard interpreting in Scotland, some instances of which have been documented. The situation has even led to the collapse of a number of prosecutions, at considerable cost to the taxpayer and to the detriment of the administration of justice (see Bynorth 2008). In 2002 the Scottish Executive's Central Research Unit published a literature review entitled Translating, Interpreting and Communication Support Services Across the Public Sector in Scotland (McPake and Johnstone 2002). The purpose of this review was "to inform the Translation, Interpreting and Communications Support Services Framework Group in its work to develop a 
national cross-sectoral framework of standards for these services. Guiding principles for the work of this group include the goal of meeting the communications support and language needs of the community and avoiding discrimination through failure to deal with these issues and other barriers to equal access" (Scottish Forum for Public Service Interpreting and Translating, 2000: Good Practice Guidelines; cited in McPake and Johnstone 2002: i). However, the document's abundant insights, references, information about policy options, including material on guidelines and standards, ensuring quality of interpretation and support for interpretation, monitoring and evaluation have clearly not been acted on by the criminal justice system in this particular part of Great Britain. The influx of Eastern Europeans into Scotland in the early 2000s arising from the expansion of the European Union resulted in a sharp rise in demand for certain languages. As a result of dissatisfaction with the existing situation, in March 2009 the Scottish government issued an Invitation to Tender for the Provision of Interpreting, Translation and Transcription Services Framework Agreement (<http://www.publiccontractsscotland.gov.uk/Search/ Search_Print.aspx?ID=MAR059861>). The approach outlined in the tender was designed to:

- Improve quality and coverage of Service Delivery, measured against clear and consistent Key Performance Indicators

- Improve sharing of knowledge and best practice

- Increase efficiencies in process and reduced duplication of procurement effort

- Increase efficiencies in process and reduced duplication from implementation of statement billing

In connection with this administrative move, Taylor quotes a Scottish Court Service Spokesperson as saying: "The Scottish Court Service has to provide translators to support the delivery of justice within courts. This new contract delivers better value for public money, greater efficiency, and the Scottish Court Service requires translators to have the Diploma in Public Services Interpretation" (Taylor 2009). The absence of any mention of quality of interpreting services in this quotation is noteworthy.

The upshot of the award of the tender was a deterioration in court interpreters' working conditions. Concerned at the country's unsatisfactory courtinterpreting situation, in late 2009 Scotland's professional interpreters set up a new professional body, the Scottish Association of Interpreters \& Translators (SITA). Some of the new association's members reportedly threatened to boycott court hearings and hold demonstrations to highlight their cause. "They claim that inadequate translation services could lead to foreign nationals either being wrongly convicted or escaping justice," writes McLaughlin 
(2009), going on to cite the Miscarriages of Justice Organisation Scotland (MOJO) as saying that the cutting of costs signals a "very dangerous move", and threatens to undermine defendants' rights to a fair trial under the European Convention on Human Rights. In addition to due process and accessto-justice criteria, the working conditions offered to the interpreters under the 2009 tender are presented as being extremely unsatisfactory. According to McLaughlin's report, the arrangement means that even self-employed interpreters with years of experience are guaranteed only $£ 36$ for a day's work, inclusive of travel costs: "Many say they are being 'starved' out of their profession as a result - one veteran is now eking out a living as a taxi driver - and replaced by individuals with insufficient training and a potentially dangerous ignorance of the legal system". Under the new rules introduced by the new agency to which the tender has been awarded, Scottish interpreters have in effect had their pay cut insofar as for the first 70 miles interpreters in Scotland will not be getting paid for either their travel time or travel expenses (http:// si-ta.org/forum).

Whereas interpreters in California tend to be both qualified and experienced and also employees of the court system, not infrequently they are frustrated as the result of a lack of a career path. However, few of them seem to leave the profession. In contrast, in many parts of England and Wales, as well as in Scotland and Ireland, quality standards are tending to fall rapidly as a result of a poorly designed and poorly managed outsourcing system based on the use of freelance interpreters. The well-qualified may leave the profession as a result of their inability to earn a living wage under the pernicious outsourcing system, leaving only the inexperienced and incompetent to service the justice system.

Best practice in New Jersey and the Southern District of New York: and a sorry tale in Arizona

In the outsourcing-oriented world of the early twenty-first century, subcontracting what is wrongly perceived as a commodity often seems to the administrators of court systems a way to solve all their problems with providing interpreters. Increasingly, however, this apparently attractive option is coming to be perceived by those who can see further than pennies and cents, and are both provided with and listen to feedback from the courts, as being associated with serious problems over interpreter quality and provision. Sometimes an "in-house" interpreter's office is considered the better solution. Here too the human factor can be all important, on all levels. In the State of New Jersey, for example, the influence of a supportive Chief Justice in the 1980s helped 
launch a language services section in the Administrative Office of the Courts which supports the Judiciary's goal of ensuring that persons with limited English proficiency (LEP) have equal access to the courts and support services (personal communication). New Jersey's Language Services "seeks to improve court interpreter services by coordinating the court interpreter testing program; developing and implementing policies in related areas, and performing administrative tasks such as managing statistics, providing the Registry of Interpreting Resources and piloting new ways of enhancing delivery of interpreting services". The recently retired long-serving head of the New Jersey Language Services Section, Robert Joe Lee, played a major role in not only guaranteeing stability but also striving to constantly improve the provision of both spoken and sign language interpreting in the State's courts, and to keep up with trends resulting from migration and other developments (see http:// www.judiciary.state.nj.us/interpreters/index.htm). The same can be said of the head of the SDNY Interpreters Office which serves the U.S. District Court in the Southern District of New York. Working conditions and interpreter quality are incomparably better at the latter than at the State Court a few hundred meters down the road (personal observation). Financial aspects are only part of the explanation for the edge that interpreting at the Federal court has over its state counterpart, as is clear from the professionalism reflected in its website. In particular, attention is drawn to the various parts of the "Best Practices" tab, where separate documents address issues specifically arising for judges, assistant US attorneys, attorneys examining witnesses through an interpreter, and translations (see http://sdnyinterpreters.org/). As in the New Jersey case, the long-serving head of and chief interpreter at the SDNY Interpreters Office, Nancy Festinger, is responsible for much of the professionalism of everything provided by her section. Even in such a well-run, well resourced courthouse such as the Federal Court for the Southern District of New York, lawyers and judges are proactively encouraged and helped to follow best practice by the court interpreting section (see Festinger 2003). Clearly best practice does not just happen: it has to be made to happen and efforts must be invested in keeping it that way.

Elsewhere in the country, in Arizona, another, far more dismal picture emerges. In an article entitled "Requiem for an Interpreters Office, 1985 2001" (Anonymous: Proteus, NAJIT Newsletter, 10:3), the author (who asked that his/her identity not be revealed), outlines how from the mid-1970's standards were established in Maricopa County in parallel with the work carried out in California and nationwide, following the passing in 1979 of the Federal Court Interpreters Act. Up until 1978, "interpreters" in Maricopa County were 
bilingual law library clerks sent to "help out" when needed in the courtroom. That year an examination began to be administered, "although the way it was scored left a great deal to be desired as to validity and reliability" (Anonymous 2001). The Phoenix staff interpreters set to work on establishing standards, creating a professional organization and drafting proposed legislation to set a minimum competency level for court interpreters. In Maricopa County, these efforts were successful: an Office of the Court Interpreter (OCI) was created, with a chief interpreter position and a body of rules and regulations written and approved by the bench. "By the early 1980's, the structure of the qualifying exam had been streamlined, professional interpreters were hired and the quality of interpreter services rose appreciably" (Anonymous 2001). By 1985, the county had three staff interpreters and a pool of five qualified freelance interpreters. The interpreting department at the Superior Court in Maricopa County had by this time earned a national reputation. The office administered its own written and oral examinations and the court respected the qualification procedure. Interpreter salaries were the highest in the state. The professional atmosphere attracted "people with the right stuff".

However, by 1986, the administrator and the presiding judge who had overseen and supported the steps taken by the Phoenix staff interpreters were both gone, the former to retirement, the latter to the federal bench. Then came a change in administration at the Superior Court that would impact interpreter practice for the rest of the century. The new administrator and presiding judge showed scant interest in maintaining the standards previously agreed upon. Over the next few years, the court administrator re-classified many positions. The court administration eliminated the role of staff interpreters in administering the written examination, setting their own interviews, orienting new judges on interpreting issues, evaluating interpreter practice, discussing policy as it affected their practice, and recruiting potential staff interpreters. By the mid-1990's, the court administration side-stepped the county's human resources department and created its own in-house department for personnel matters. This department was charged with interpreter recruitment, although many other positions continued to be recruited through the county system. Under their aegis, the number of qualified interpreter candidates plummeted: in just three years, the number of applicants passing the written test was reduced by more than half. Senior interpreters believed this was because the court's human resources department failed to identify and attract competent practicing interpreters from other jurisdictions.

The court administrator and human resources director created a new position, called a "staffing services manager". The position was filled by a person 
with a graduate degree in language, whose work experience includes banking and teaching Spanish to the CIA. This new manager's mission was to hire more interpreters, or to be precise, to "fill interpreter positions". The oral exam (in use to qualify interpreters since the 1980s) was waived. New applicants were required only to take a written exam (a multiple-choice language competency test) and have an interview. The requirement in the job description, that interpreters have at least one year of paid professional experience, was waived.

The anonymous author of the "requiem" finished with the following lament:

The state association has no influence over practice in the field. No statute, rule of court, or policy is in place stating that interpreters need any qualification other than the avowed ability to speak Spanish.

For many years, we worked hard to create a professional practice that many judges took for granted as the norm. No one on the bench now remembers how interpreters struggled back in the seventies: most of the new judges were in high school then. Speed is now of the essence in all things judicial, and the Office of the Court Interpreter has all but in name been dismantled. Let us have a moment of silence. (Anonymous 2001)

The question that must be asked is this: Which is more representative of court interpreting practice in the US federal and state court system: the best practice that was achieved by the mid-1980s in Arizona, or the dismal, "dumbeddown", non-professional approach that subsequently replaced it? At the end of the first decade of the twenty-first century, can it be said that, in the United States, on both a Federal and a state level, on the whole professional standards and certification prevail, for Spanish at least, which represents a very large proportion (around 90\%) of all interpreted proceedings? What is undeniable is that increasing globalization has led to greater linguistic diversity in the court system, both civil and criminal, of many countries. The greater numbers of those who need and are being provided with interpreting services necessarily constitute an additional burden on the cash-strapped judicial system and the taxpayer.

\section{The cost of judicial lack of awareness of best practice: Pagoada in Kentucky}

In addition to the quantitative problems caused by the results of an increasingly globalized world, there always remain pockets of ignorance: for example, some judges are not aware that being bilingual is not the same as being able to interpret competently, nor that there is a major difference between 
translators and interpreters. Costly appeals, not to say miscarriages of justice and retrials, have resulted from such lack of awareness. While certain states and cities make major efforts to secure appropriate interpreters and strive for best practice, others lag behind, sometimes grievously. Where there has been progress, as in Maricopa County, Arizona, ground may subsequently be lost, and headway gained can be sacrificed to administrative mismanagement. On the other hand, awareness is creeping in and some states are gradually making up lost ground.

The 2001 Kentucky case of Santos Adonay Pagoada is representative of those jurisdictions which previously had no need to address interpreting issues. Pagoada, a 32-year-old Honduran man, had been sentenced in his original trial to 40 years on a murder conviction. In the Pagoada appeal, Judge Noble identifies the issue at stake - the quality of interpreting at previous proceedings and hence whether Pagoada received a fair trial on murder charges - and refers to this as "a question of first impression" for Kentucky. Hence, she goes on to say, "the Court has read and studied for the past year, trying to get a grasp on the scope of the problem, and how to adequately address it" (Pagoada v. Kentucky, No. 97CR-1002, p. 1). The essential point in the court's reasoning was that in order to be "present" and to be able to participate in his defence, Pagoada had to have an acceptable level of understanding of the proceedings.

Framer (2001) discusses and analyses the issues arising in the case. She notes that during a crucial part of the trial, the judge held a side bar with the attorneys, Pagoada, and the interpreter with the commendable intention of making absolutely sure that the defendant understood his right to testify or not to testify. At times, however, the interpreter's rendering was nonsensical, composed of words that sounded like Spanish but which are not part of the Spanish lexicon, such as "carecto," "satusfichado," "factos," and "consecuencas". Instead of the word "vida" which means "life" in Spanish, she used the word "libra", which means "scale" in Spanish. Framer observes that the effect was that of listening to somebody imitate a person speaking a foreign language. The interpreter also carried on independent conversations with the defendant and did not interpret these conversations back to counsel or the judge. However, the judge was unaware of the abysmal quality of the interpreted version. Framer provides a small excerpt to illustrate the tenor of these exchanges:

Judge: And based on their decision, if he is convicted if they find him guilty of any level on which I instruct.... 
Interpreter [to Pagoada, in Spanish]: In their decision, in any part of the court if it's high low it's theirs, they will make the decision.

Judge: As to whether he committed the murder.

Interpreter: [in Spanish] If you committed the assassinated.

Judge: Here is what he needs to know. If he is, if he believes that he can convince a jury that he was defending himself, he needs to make that decision as to where enough has been said, or if he needs to say more.

Interpreter: [in Spanish] She says that the [judados] are going to make that decision. If you think that they have heard a lot of evidence to defend you, that you were defending your life, then that's fine, but if not, then you should give them an explanation why you think you, you were defending your life. Do you think that they did hear lots of evidence to say, oh yes, this guy was defending his life?

Judge: All right then, I think that whether he accepts it or not, it has been explained to him as adequately as it possibly can be. (Framer 2001)

Clearly the judge was acting on the assumption that what he said was being accurately conveyed to and understood by the defendant, not that he was being provided with something that was closer to nonsense in Spanish. The underlying reasons for this assumption were stated clearly in the decision on the Pagoada motion:

- Out of ignorance, all assumed that one who speaks Spanish or is born in a Spanish-speaking country can interpret. This case reveals that this is a false assumption. (3-4)

- No distinction was made between interpreting skills and translation skills, which according to testimony differ considerably, so that one who can translate adequately from the written word may well lack the skills to interpret orally and simultaneously in the legal context. No one was aware of this distinction at the time. (Pagoada v. Kentucky: 4)

The Pagoada court then succinctly stated the consequences of this failure to provide proper interpreting services, for both Pagoada himself and for fundamental due process: "Because Pagoada did not have accurate, comprehensible statements made to him for most of the interpretation, his position is analogous to that of persons under a disability in competency proceedings" (Pagoada v. Kentucky: 5).

After observing that there is nothing easy about any trial where liberty is at stake and a victim is at loss, and that it is even less so when there are multiple languages involved, the court summed up by saying: "However, fundamental due process requires a level playing field, and that all persons answering to the law of the land be given a similar opportunity to answer" (Pagoada v. Kentucky: 7). After observing that Pagoada was entitled to such fairness regardless of his ability to speak and comprehend English, it concluded: "Perfect 
understanding is not required to mete fairness, but a reasonable understanding is" (Pagoada v. Kentucky: 7).

In an 'author's note' to her 2001 article about Pagoada's original trial, Framer identifies the major difference that competent interpreting can make. She reports that in April 2002, after a successful appeal for ineffective assistance of counsel that went hand in hand with the use of untrained and unqualified interpreters, Pagoada won a new trial, where he was provided with two federally certified interpreters. While eleven jurors favoured acquittal one juror held out. Ultimately, after deliberating for 10 hours and being sequestered overnight, the jurors compromised to find Pagoada guilty of reckless homicide, and he was released from prison for time served. It would not be overstating the case to say that the competent interpretation at the retrial made all the difference between the original 40-year jail sentence for murder and being found guilty of reckless homicide at a retrial.

\section{Dealing with rare languages in the United States - Vai in Maryland (Kanneh) and Tigrinya in Florida (Tesfamariam)}

On a brighter note, interpreter networking, particularly using email, to locate appropriate individuals for rare languages has become common at the time of writing, and is often far more effective than the efforts of a court secretariat. Two early twenty-first century cases will illustrate the point effectively. One involves bad practice; one good. One is the Maryland case of Mahamu Kanneh, who was indicted in December 2004 on nine counts of rape, sex abuse and child abuse in the Circuit Court for Montgomery County. His trial was repeatedly postponed over a 35 month period for a variety of reasons, mainly the time it took to process the DNA evidence, and above all the court's inability to secure a qualified interpreter in the defendant's native language, Vai. The lower court eventually dismissed the case on the grounds that the defendant's right to a speedy trial had been violated (State v. Kanneh, 403 Md. 678).

The State of Maryland appealed. In its conclusion, the Court of Appeals of Maryland observed that although the delay in this case was significant, in light of the complex nature of the case, "[b]ecause there was no bad faith on the part of the State in securing or failing to secure an interpreter, which was the primary reason for the delay" (State v. Kanneh, $403 \mathrm{Md}$. 678 at 694), it found that this factor did not weigh heavily against the State. In fact, the State had managed to locate three Vai interpreters, the last of whom was in fact present at the last hearing at which the charges were dropped. At a motions 
hearing on November 1, 2005, the parties discussed their efforts to secure an interpreter for Kanneh. Neither the State nor Kanneh's attorney had been able to locate an interpreter, and for that reason, the trial judge postponed the case until January 23, 2006. At a motions hearing on January 13, 2006, although it appeared that the parties had found an interpreter, "they realized that this interpreter was not qualified to perform simultaneous interpretation for a trial that had the potential to last four or five days" (State v. Kanneh, $403 \mathrm{Md} .678$ at 686). As a result, the trial judge postponed the trial date until May 8, 2006.

Again, at a motions hearing on May 3, 2006, the parties informed the court that it was likely that they would be unable to secure an interpreter by the trial date, and the trial date was postponed until October 16, 2006. The Court of Appeals document indicates that the court did subsequently locate an interpreter; however, "because of that interpreter's personal feelings regarding child abuse cases, she left the courtroom and did not return" (State v. Kanneh, $403 \mathrm{Md}$. 678, footnote 5 at 687); later someone else was secured to interpret the proceedings, and she was present during a motions hearing on February 16, 2007. On that date, however, the interpreter indicated that she had "just had some pretty serious surgery" and the court rescheduled the trial date for July 30,2007, because it would be "cruel and unusual to expect a person having just had some major surgery to be compelled to be here in discomfort" (State v. Kanneh, 403 Md. 678, at 687).

A newspaper report indicated that many of the appellate judges seemed sceptical that Kanneh really needed an interpreter in the first place, since he had lived in the United States for years and attended high school there. However, the assistant attorney general involved said that Kanneh's attorney argued at the circuit court level that Kanneh could understand basic English but did not know enough to help with his own defence; furthermore, the prosecutor wanted to protect Kanneh's rights and so made every attempt to accommodate his request (Tamber 2008: 1).

Although the trial judge, Katherine Savage, stated when she granted Kanneh's motion to dismiss the charges that the efforts to get an interpreter had been "Herculean", according to Tamber, the assistant public defender disagreed. Tamber quotes the latter as saying: "I would suggest to the court that what we have in terms of the court's efforts, the timing of the efforts, the record does not support that there was a diligent pursuit of a translator or an interpreter from the get-go..." (2008: 1). In fact, with help from the National Association of Judiciary Interpreters and Translators, The Washington Post identified three Vai interpreters Thursday, including one in Gaithersburg. Lionbridge, a company that offers interpretation services, reportedly said it 
could provide Vai speakers on short notice (Londoño 2007). Immigration officials took Kanneh into custody after the state charges against him were dropped, and a deportation order was entered in November 2007 (Grzincic 2008).

A contrasting case involves a Tigrinya-speaking defendant on murder charges. The authorities in Broward County, Florida, had to find a Tingrinya interpreter to translate for Mesfin Tesfamariam, a man from Eritrea who had been in the United States for only about a year prior to his arrest on murder charges in July 2007. The supervisor for the Broward court interpreters, Ramon Grau, "had to sift through local contacts to eventually track down Tekeste Bereket, from New Jersey". Grau commented, "This doesn't happen very often. Sometimes interpreters have to come from Palm Beach or Miami, but never New York or New Jersey, and not this type of language or dialect". Money from the state court's revenue trust fund paid Bereket's $\$ 600$ daily fee, airfare, lodging and meals (Alanez 2009). Succinctly put, where there's a will and a willingness to pay appropriately, there's a way.

\section{Canada: Mr. Justice Casey Hill and Sidhu}

Over the border, in Canada, practice is similarly patchy. As far as French and English are concerned, on the whole the situation is satisfactory. However, the same cannot be said of other languages. The following account reflects the power that can be exercised by an unprofessional, lazy, negligent and recklessly uncaring individual in the position of interpreter coordinator, combined with the judicial authorities' blatant ignoring or failure to heed complaints about interpreters, training, monitoring and procedures raised by inquiries, judges, prosecutors, counsel and even Ministry staff.

A judicial study of interpreting in one of Ontario's busiest and most multicultural courthouses revealed that for five years it had been using interpreters who are so woefully unqualified that they routinely failed the provincial accreditation test and, in some instances, may not have been able even to read the language they were being paid to interpret. It was when Mr. Justice Casey Hill began hearing what he originally believed would be an ordinary appeal alleging unacceptable trial delay at the Peel Region courthouse that he discovered, instead, the scandal that was long in the brewing. This courthouse, which opened in 2000, is Ontario's second largest and, as Justice Hill noted, "with the jurisdiction's multicultural demographics, [...] the highest user of interpreters" in the province, serving a daily transient population of tens of thousands. Yet despite the inherent vulnerability of so many Peel Region residents - newcomers to Canada not fluent in English, sometimes poor and 
likely to be easily intimidated by the court process - those accused of crimes were often abjectly served by the justice system.

Mr. Justice Hill heard evidence that from 2001 through the early part of 2007, unaccredited interpreters - responsible for translating a total of 10 languages into English - who had failed the Ontario test at least once had worked a total of 2,670 days. In the same time period, 19 interpreters - translating 25 other languages - who had never taken the test at all worked 592 court days. This information is contained in a review of interpreter invoices, a document which according to Mr. Justice Hill reveals that "for years, in addition to trials," these unaccredited and unskilled interpreters worked assignment court, contested bail hearings and consent releases and guilty pleas and sentencings at both the Ontario Court and Superior Court levels (R. v. Sidhu, para. 252). Though the problem was revealed in the summer of 2004 to Justice and government officials, the practice continued in Peel Region, with Justice Hill noting that in 2007 alone, unaccredited interpreters were used 54 times in court, and unaccredited interpreters who had failed the test worked in 96 instances (Blatchford 2005a).

While the judge found that much of the blame for the situation in Peel Region lay with two individuals - a woman named Forouz Masrour, a government employee since 1991 and the "interpreter co-ordinator" for the provincial Attorney-General's Ministry in Brampton, and Gerri Wyatt, the supervisor of court operations - he also found that "management ignored or abandoned constitutional and access to justice values unreasonably discounting the seriousness of the concerns involving [the interpreter's] interpretation competency" (R.v. Sidhu, para. 323), minimized the complaints that were coming in about the interpreters, and viewed what was a key 'access to justice' matter as a labour-relations problem (Blatchford 2005a).

The following situation graphically illustrates the kind of situation that can result from careless, not to say potentially criminally reckless unethical behaviour, in this case by an interpreter co-ordinator. A Hindi-speaking woman called Manjeet Bhandhal was hired at the Brampton courthouse at a time when what they needed was a Punjabi-speaking interpreter. Ms. Bhandhal was apparently quite open that she had never spoken Punjabi before in her life, but was nonetheless assigned to do just that in weekend bail courts. An official with the Ontario Attorney-General's ministry told Judge Hill that he believes Ms. Bhandhal cannot even read Punjabi. It appears that the quality of her interpretation played a role in a case that ended in a mistrial. The person who assigned her was Forouz Masrour, the interpreter co-ordinator at the courthouse. In her evidence before Judge Hill, she admitted that she 
considered weekend bail court "a game" because "there would not be anyone who would create problems" there. "Apparently, the fact that at bail court, accused people can lose their liberty was not a pressing concern for Ms. Masrour" (Blatchford 2005b).

Against this background, in April 2008 a class action was instituted in the Ontario Superior Court of Justice against the Ministry of the Attorney General of the Province of Ontario (Sidhu vs. Ministry of the Attorney General). The action, it is stated, arises out of the Province's failure to provide competent interpreters in court proceedings, and the class proceeding is on behalf of all individuals who have suffered because of incompetent interpreters. The claim asserts that the Ministry of the Attorney General's Court Services Division is responsible for providing competent interpreters in court proceedings. However, it is alleged that the Province has used unaccredited individuals as interpreters without advising the court, the parties or counsel, and that the Province does not adequately train, test or monitor interpreters. It is further alleged that the Province continued to use incompetent interpreters even after it became aware that they were not competent to interpret court proceedings. The Province is alleged to have ignored or failed to heed complaints about interpreters, training, monitoring and procedures raised by inquiries, judges, crowns, counsel and even Ministry staff (Girard 2007).

\section{Court interpreting: An undervalued and misunderstood profession, or reason to hope?}

After this bird's eye view of the court interpreting situation in a number of jurisdictions, we are left with a number of questions, rather than ready answers. Can legislation help? Despite Section 14 of Canada's Charter of Rights and Freedoms, Mr. Sidhu did not get a fair trial because the interpreter who was provided was not competent. In Ohio, will the Franklin municipal court's detailed requirements attract a competent individual at the meagre salary being offered? Even if Senator Kohl's federal grant program is passed, will it in fact ensure that high quality interpreter services are made available to non-English speakers appearing in court? In the USA, is the shortage of qualified court interpreters in state courts a result of a lack of funding that can be addressed by the authorizing of $\$ 15$ million per year, over five years, for a State Court Interpreter Grant Program? If states are given assistance to develop, implement and improve state court interpreter certification programs in order to ensure fair trials for individuals with limited English proficiency, will those authorities that need these court interpreters actually pay them sufficiently well to make the profession of court interpreter one to which suitable 
individuals will be attracted, and will it become a career? Can Canada's Sidhu class action, if it succeeds, change the outlook and concomitant practice of the Ministry of the Attorney General of the Province of Ontario? If, as is alleged in this class action, the Province of Ontario has ignored or failed to heed complaints about interpreters, training, monitoring and procedures raised by inquiries, judges, crowns, counsel and even Ministry staff, what is the point of striving for quality? Are such efforts condemned to failure? Is this specific to Canada, or is it made special by the detailed action taken by Mr. Justice Hill in combination with several concerned lawyers to ferret out and publicize the shameful truth?

Perhaps a pessimistic note is not justified. While admitting that the failings identified in the Brennan Report "take a heavy human toll", and often violate federal law, Abel goes on to point out: "Fortunately, the picture is not entirely bleak. Each of the failings is avoidable" (Abel 2009: 2). She notes that in the last decade, the states have begun to develop programs to recruit, test and assign court interpreters. At least 40 states have joined the Consortium for State Court Interpreter Certification, to obtain access to exams assessing the competence of their interpreters. As a result, states seeking to improve their interpreter programs have examples to follow. Encouragingly, she reports, a revitalized federal Department of Justice is now energetically enforcing civil rights laws. And federal legislators are looking for ways to provide state court systems with additional funding for essential court interpreter services. "With this report," she writes, "we hope to facilitate and accelerate all of these efforts, to help states meet their obligations, and to ensure that, in the end, justice will speak" (Abel 2009: 2). Washington State, Oregon, California, New Jersey, New York and a few other states do well at providing competent interpreters in criminal and often civil cases. Most larger states and metropolitan cities are doing well for the most part. In contrast, in rural counties and in states with a smaller limited-English speaking population, there tend to be no training, no policies, and no interpreter program. Some systems outsource to commercial language agencies with no knowledge, no training, and no standards.

Is there any hope that the situation in Scotland will improve? Over a period of more than a decade, research identifying issues, literature reviews and the introduction of an outsourcing system do not appear to have brought about any improvement. Will outsourcing in Ireland remain a fact of life despite user dissatisfaction with the service provided? Is there any chance that interpreters in California, dissatisfied with their lack of career prospects, will leave the profession? Will training and continuous education be introduced 
for court interpreters as part of their career development? Will the judicial profession come to understand the professionalism that is needed in order to provide competent court interpreting? Only time will determine the answers to these and numerous other questions. Advocacy on the part of court interpreter associations and their members continues, but as economic and other factors increasingly come to the fore in determining practice in the legal system, the likelihood of positive change diminishes.

Those concerned about court interpreting issues should not only hope for improvement, but also continue to work to ensure that court interpreting is no longer an undervalued and misunderstood profession. It would be good to think that within a reasonable time span, the question in this article's subtitle - "will justice speak?" - will no longer need to be posed. Experience, however, has shown that this may be wishful thinking. Writing about the contractual provision of interpreters to public services in Scotland, Lalmy (2009) writes: "Now let's consider how this set up between agencies and the public service users has worked so far. The first thing to say is that it did not work out as well as it should have". In terms of performance, he argues, there has been a failure because of what he identifies as "complacencies" from both the agencies in providing unqualified interpreters and from the public services who "unquestionably accept their services despite previous appalling experiences". Lalmy further points out that despite the various press headlines over the last five years or so pointing out those agencies failing to provide adequate interpreters, he has still not come across a case where public services have sued an interpreting agency for breach of contract. He wryly comments that it can only be assumed that "the loop[hole] in the system is exploited by one party and accepted by the other", relying mainly on footnote (i) in the Crown Office and Procurator Fiscal Service Protocol which states: "On occasion it is recognised that interpreters who do not have the preferred qualifications and experience will require to be engaged". Writing in 2009, Lalmy argues that over the last decade there was plenty of time for the agencies to bring up to standard those interpreters not fully qualified on their register, and such an exception would solely apply to a very specific dialect from a remote part of the world. This particular loophole seems to be responsible for the yawning abyss between stated intentions about best practice and actual deficient hands-on practice that enables the Scottish legal system to continue, under a brand-new tender, to perpetuate its former shortcomings. Scotland is but one example of a legal system's attitude to the undervalued and misunderstood profession of court interpreting. 


\section{Epilogue}

The same month that Franklin County Municipal Court published its demanding notice of vacancy for a court interpreter, it fired a Spanish-language interpreter who had been employed there for two and a half years because he could not interpret legal terms, "possibly jeopardizing the constitutional rights of thousands" (Czekalinski 2009). According to court documents, the individual in question made up words, including the Spanish word for "defendant," and guessed when he did not understand legal terms in English. Furthermore, in a June 2009 hearing regarding his qualifications, the man in question testified that he had "not mastered legal vocabulary in English or Spanish, for sure," but because everything is repetitive in the courtrooms he had a "well-enough grasp of actual phrases and words". The Columbus Dispatch report finished with the bald statement that there was no standard qualification process for interpreters in Ohio, according to a 2006 Supreme Court report. "At that time, 32 percent of interpreters working in Ohio's courts had received no related training" (Czekalinski 2009).

\section{Footnote: Losing a child in the translation}

Most of this article has focused on interpreters who work in the court system. However, the ramifications of inadequate linguistic arrangements by the public services inevitably have a far wider impact on the lives of second-language speakers than the narrower court setting, although often that is where those affected finish up. For example, a US Spanish-language radio programme at the beginning of June 2009 discussed the forced-adoption case of Chatina migrant Cirila Baltazar. It was reported that a court in Mississippi was about to terminate the parental rights of this Mexican immigrant woman, who was also facing the risk of deportation. By court order, the US born child was subsequently given in adoption to a local family. Advocates were challenging the process arguing that the woman, a Chatino-speaking migrant from the highlands in Southern Mexico, had not been able to defend herself (<http://www. archivosderb.org/?q=en/audio/by/guest/cirila_baltazar_cruz>).

On its website, the National Network for Immigrant and Refugee Rights (NNIRR) noted that the hospital provided her with an "interpreter" who is from Puerto Rico and does not speak Chatino, the language of the mother. Because of the language barrier and the misunderstanding by the hospital's interpreter who only spoke Spanish and English, a social worker was called in. The latter reported "evidence" of abuse and neglect because, according to the NNIRR report, the "baby was born to an illegal [sic] immigrant"; the "mother 
had not purchased a crib, clothes, food or formula" (most Latina mothers breast feed their babies); "she does not speak English which puts baby in danger" (<http://www.nnirr.org/action/index.php?op=read\&id=229\&type=0 >).

The NNIRR report further stated that Ms. Baltazar Cruz's baby was removed from her two days after birth at the hospital and given to an affluent local attorney couple who were unable to have children. The authorities made no effort to locate a Chatino interpreter, Ms. Baltazar Cruz's native tongue. Organizers from MIRA, the Mississippi Immigrant Rights Alliance, located an interpreter who is fluent in Chatino in Los Angeles and with her help interviewed the mother extensively.

The mother, the report continued, was accused of being poor and not being able to provide for her child. No one asked the mother to provide evidence of support. Reportedly she owns a home in Mexico and a store which provides both secure shelter and financial support, not counting the nurturing of a loving family of two other siblings, a grandmother, aunts, uncles and other extended family.

Through the Internet, at least, appears that there is some chance of justice speaking, even if it is in a whisper.

\section{References}

Articles, reports and books

ABEL, Laura. (2009) Brennan Center for Justice Report on Language Access in State Courts. Full-text version at: <http://brennan.3cdn.net/ c611a37ee2b6eb199e_9bm6b3so4.pdf>

Alanez, Tonya. (2009) "African language gap bridged in Broward murder trial". South Florida Sun-Sentinel, July 16, 2009. Full-text version at: <http:// www.sun-sentinel.com/news/broward/sfl-ethiopian-dialect-interpreterb071609,0,2134135.story>

Anonymous. (2001) "Requiem for an Interpreters Office, 1985-2001". Proteus, NAJIT Newsletter, 10: 3. p. 13.

BLATCHFORD, Christie. (2005a) "Inept court translators called 'threat to justice". Globe and Mail, November 18, 2005.

BLATCHFORD, Christie. (2005b) "How do you say 'chaos' in dozens of languages?". Globe and Mail, November 19, 2005.

BYNORTH, John. (2008) "Justice system compromised by unqualified interpreters: Fears of miscarriages in cases involving migrants". Sunday Herald, May 25, 2008. Full-text version at: <http://www.sundayherald.com/news/heraldnews/ display.var.2295799.0.justice_system_compromised_by_unqualified_interpreters.php> 
Commonwealth Attorney-General's Department. (1991) Access to Interpreters in the Australian Legal System. Canberra: Australian Government Publishing Service.

CZEKALINSKI, Stephanie. (2009) "Court interpreter fired: Man allegedly made up, mistranslated terms in Spanish". The Columbus Dispatch, August 1, 2009. Full-text version at: <http://www.dispatch.com/live/content/local_news/stories/2009/08/01/misinterpreted.art_art_08-01-09_b1_c3el5fk.html?sid=101>

EADES, Diana. (1992) Aboriginal English and the Law: communicating with Aboriginal English-speaking clients: a handbook for legal practitioners. Brisbane: Queensland Law Society.

FESTINGER, Nancy. (2003) Courthouses in a Multilingual Society: Maintaining Good Relations with Your Court Interpreters. CM \&A, The Court Management and Administration Report, Vol. 13, No. 2 April-June 2003. Full-text version at: <http://www.nyc.gov/html/oath/pdf/Courthouses\%20in\%20a\%20Multilingual\%20Society.pdf>

FrAMER, Isabel. (2001) "Through the Eyes of an Interpreter". The Advocate, The Kentucky Department of Public Advocacy, 23:3. Full-text version at: <http://dpa.state.ky.us/library/manuals/inter/eyes.html>, <http://www.ccio.org/ CCIO-Resources-through\%20the\%20eyes.htm>

FrAMER, Isabel. (2002) "Author's note". Full-text version at: <http://languageaccess.us/uploads/Through\%20the\%20Eyes\%20of\%20an\%20Interpreter\%20 Author's\%20Note\%20PDF.pdf>

GIRARD, Michael. (2007) "Class Action for Breach of Minority Charter Rights". Full-text version at: <http://cacounsel.com/>

GRZINCIC, Barbara. (2008) "Maryland Court of Appeals revives case against Vai speaker". The Baltimore Daily Record, Mar 17, 2008. Full-text version at: <http://findarticles.com/p/articles/mi_qn4183/is_20080317/ai_n24936353/>

HAYES, Elizabeth. (2007) Editorial. ITIA Bulletin, October 2007, 1.

HonG, Peter. (2007) "Court interpreters return to work without pay raises - At the urging of a state senator, more than 300 employees vote to end a six-week walkout". Los Angeles Times, October 18, 2007. Full-text version at: <http:// articles.latimes.com/2007/oct/18/local/me-interpreters18>

HowIE, Michael. (2007) "Translation errors may see criminals escape". The Scotsman. October 30, 2007. Full-text version at: <http://news.scotsman.com/index.cfm?id=1727012007>

KoHL, Herbert. (2009) The State Court Interpreter Grant Program Act, A bill to authorize the Attorney General to award grants to State courts to develop and implement State courts interpreter programs. Full-text version at: <http://www. opencongress.org/bill/111-s1329/text> 
LALMY, Ben. (2009) "Interpreting issues in Scotland". Full-text version at: <http://lalmy.blogspot.com/2009/03/interpreting-issues-in-scotland-by-ben. html\#comment-form>

LAW ReFORM COMMission. (1992) Report No. 57, Multiculturalism and the Law. Full-text version at: <http://www.austlii.edu.au/au/other/alrc/publications/ reports/57/>

INTERPRETERS AND TRANSLATORS BULlETIN. (n.d.) "Malpractices Dossier: Trials lost or prosecutions compromised by poor interpreting resulting from outsourcing". Full-text version at: <http://www.interpreters-branch.org.uk/index.php? mid=6>

Central Government Centre of Procurement Expertise (CGCoPE). (2009) Invitation to Tender for the Provision of Interpreting, Translation and Transcription Services Framework Agreement. March 2009. Full-text version at: <http://www. publiccontractsscotland.gov.uk/Search/Search_Print.aspx?ID=MAR059861>

LONDOÑO, Ernesto. (2007) "Maryland Judge Dismisses Sex-Abuse Charges: Clerk Is Unable To Find Suitable Translator In Time", Washington Post, July 22, 2007, Page C05. Full-text version at: <http://www.washingtonpost.com/wpdyn/content/article/2007/07/21/AR2007072100660.html>

MCLaughlin, Martyn. (2009) "Battle of words threatens chaos in the courts". The Scotsman. 1 November 2009. Full-text version at: <http://news.scotsman. com/scotland/Battle----of.5784353.jp>

MCPAKE, Joanna \& Richard Johnstone. (2002, modified 2006) Translating, Interpreting and Communication Support Services Across the Public Sector in Scotland: A Literature Review. Scottish Executive Central Research Unit. Full-text version at: <http://www.scotland.gov.uk/Publications/2002/03/10759/File-1>; <http://www.scotland.gov.uk/Resource/Doc/156792/0042162.pdf>

NAJIT. (2009) "Letter of support to Hon. Herbert Kohl, Senate Judiciary Committee. Re: S. 1329 to authorize the Attorney General to award grants to State courts to develop and implement State courts interpreter programs". Full-text version at: <http://najit.org/documents/S1329\%20Final\%207.13.pdf>

Phelan, Mary. (2007) "Court Interpreters in the News (for the wrong reasons)". ITIA Bulletin, October 2007, 4-5.

Supreme Court of Ohio And The Ohio Judicial System. (2009) Franklin County Municipal Court - "Part-Time Spanish Interpreter", Ohio Court Job Opportunities. Full-text version at: <http://www.supremecourt.ohio.gov/Employment/FCMC_interpreter.asp $>$.

TAMBER, Caryn. (2008) "Maryland Court of Appeals weighs dismissal of delayed sex abuse case". The Baltimore Daily Record. Full-text version at: <http://findarticles.com/p/articles/mi_qn4183/is_20080213/ai_n21415043/> 
TAYLOR, Kirsty. (2009) "Scottish Court Service lost in translation". Deadline Scotland. Full-text version at: <http://deadlinescotland.wordpress. com/2009/11/01/scottish-court-service-lost-in-translation-2077/>

THE SCOTTISH OfFICE. (1998) Foreign Language Interpreters in the Scottish Criminal Courts - Research Findings, Crime and Criminal Justice Research Findings No. 11 (1996). Full-text version at: <http://www.scotland.gov.uk/ Publications/1998/12/23c1205a-9b3a-4a2c-8d55-4fd90f1bb340>

THEINER, Layla. (2003) "By Word of Mouth". Translation and interpretation services used by asylum seekers for legal advice in Glasgow. Summary report for Amnesty International. Full-text version at: <http://www.icar.org.uk/3440/ research-directory/by-word-of-mouth.html>

THE Journal Online - The Members' Magazine of the Law Society of Scotland. (2009) "Court interpreting service put out to tender. $£ 6 \mathrm{~m}$ contract offered to improve quality", 14 May 09. Full-text version at: <http://www.journalonline. co.uk/News/1006579.aspx>

THORnTON, Paul. (2009) "Interpreter shortage leaves court system tongue tied". Deadline Scotland, 7 November 2009. Full-text version at: <http://deadlinescotland.wordpress.com/2009/03/10/interpreter-shortage-leaves-courtsystem-tongue-tied711/>

TOWNSLEY, Brooke. (2007) May 2007 "National Register Newsletter". Full-text version at: <www.nrpsi.co.uk/pdf/NRPSI\%20Newsletter\%20May\%202007.pdf>

\section{Cases cited}

Pagoada v. Kentucky, No. 97CR-1002 (Fayette Cir. Ct., 5th Div, Oct. 5, 2001).

R. v. Sidhu, [2005] O.J. No. 4881 Full-text version at: <www.cacounsel.com/R_v_ Sidhu.PDF>

Sidhu vs. Ministry of the Attorney General. Full-text version at: <http://cacounsel. com/Statement_of_Claim.PDF>

State v. Kanneh, 403 Md. 678, 944 A.2d 516; 2008 Md. LEXIS 120 (2008). 